\title{
Indirect Colorimetric Estimation of Fluoride Ion in Water and Pharmaceutical Preparation Samples
}

\author{
Nief R. Ahmad* \\ Farha K. Omar** \\ * Department of Technology/ College of Environmental / University of Mosul \\ **Department of Chemistry/ College of Education for Girls / University of Mosul
}

(Received 31/8/2018; Accepted 25/10/2018)

\begin{abstract}
An indirect method for the estimation of fluoride ion has been developed.The method is based on the bleaching action of fluoride ion on the color of Ti (IV)with 2-hydroxy-1-(2-hydroxy-4-sulfo1-naphthylazo)-3-naphthanic acid (HHSNNA) complex with proportional decrease of absorbance. Therefore, the decrease in color intensity is proportionalto the concentration of fluoride ion. Molar absorptivityis $0.1166 \times 10^{4} \mathrm{l} \cdot \mathrm{mol}^{-1} \cdot \mathrm{cm}^{-1}$ atwavelength $685 \mathrm{~nm}$. Beer's lawis obeyed over the concentration range of $0.2-4 \mu \mathrm{g} / \mathrm{ml}$. The proposed method is applied successfullyto determine fluoride ion in different real water samples andpharmaceutical preparations (Tablets). The proposed method is compared favorably with Eriochrome cyanine R - Zirconium method.
\end{abstract}

Keywords: fluoride ion, pharmaceutical preparations, water samples.

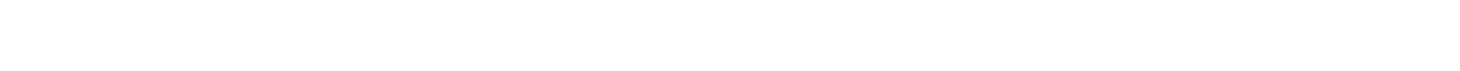

\section{ll}

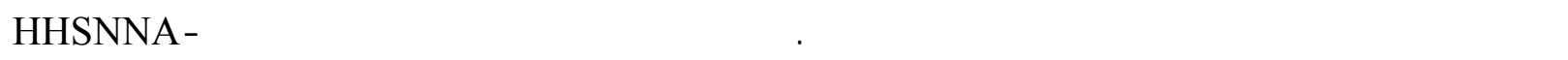
بولنطة ايون الفلوريد اذ تتنلهبشة القصر مع تركيزليون الفلوريد (0.2 -4) ميكروغرله/مل وان الامتصاصية المولاريه

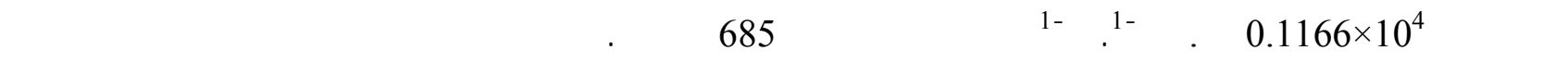
نماذج مختلفة من الميل وحبوب الفلوريد وقورنت الطريقة المقترحة معطريقة اليروكرومسيانين ار -الزركونيوم. الهاملت الدالة: ايون الفلوريد، المستحضرات الصيدلانية، نماذج ميه.

\section{INTRODUCTION}

Availability of adequate fluoride confers significant resistance to dental caries. It is now believed that the topical action of fluoride on enamel and plaque is more important than the systemic effect (British National Formulary, 2016). Fluoride is very much essential for healthy growth of teeth and bones if it present between 0.6 and $1.5 \mathrm{ppm}$ in drinking water,but if the level is higher than $1.5 \mathrm{ppm}$, it causes dental and skeletal fluorosis, decalcification, and nervous disorder, but with less than $0.6 \mathrm{ppm}$, bones and teeth will be fragile (Martindale, 2009; Dutta et al., 2010). According to WHO guideline, maximum concentration level offluoride in drinking water is 1.5 $\mathrm{mg} / \mathrm{l}$. Also the optimal fluoride range is considered to be between $0.7-1.2 \mathrm{mg} / \mathrm{l}$. The range is based on average ambient air temperature of 50 to $90 \mathrm{~F}^{\circ}(\mathrm{WHO}, 2004)$. The lethal dose for adults is $0.2-$ $0.35 \mathrm{gm} \mathrm{F}^{-}$per $\mathrm{kg}$ body weight. Fluoride is widely used in various branches of industry (Tokalioglu et al., 2004). Fluorides are released into the environment naturally through the weathering of minerals, industrial products, and phosphate fertilizer (Okibe et al., 2010). The methods for the determination of fluoride fall into three principle groups: classical titrimetric (United States 
Pharmacopeia, 2018) and spectrophotometric (Barghouthi and Amereih, 2012; Farajzadeh, 2004; Lida et al., 2013). The potentiometric methods (Tokalioglu et al., 2004) are most widely used for the determination of fluoride,but they are not so good in low level fluoride samples (Dutta et al., 2010). Therefore, the use of spectrophotometryis still investigated.Spectrophotometric methods can be classified into two categories; Direct methods based on mixed ligand complex formation (Okibe et al., 2010) and indirect methods based on substitution of colored complexes with $\mathrm{F}^{-}$ (Javad et al., 2009; Suresha et al., 2006). In this work, the reaction between Titanium (1V) and HHSNNA is used for the determination of fluoride in real water samples and pharmaceutical preparations.

\section{EXPERIMENTAL}

\section{Apparatus}

A Genway 6405 UV / visible spectrophotometer with $1.0 \mathrm{~cm}$ quartz cells and Genway 3310 $\mathrm{pH}$ meter were used.

\section{Reagents}

All chemicals used are of analytical or pharmaceutical grades.All glassware was soaked in nitric acid for $24 \mathrm{hrs}$, rinsed with distilled water before use.

\section{Titanium Stock Solution (100)ppm}

This solution is prepared by fusing $0.167 \mathrm{~g}$ of $\mathrm{TiO}_{2}$ with $1.5 \mathrm{~g}$ of $\mathrm{K}_{2} \mathrm{~S}_{2} \mathrm{O}_{7}$. The melt after powdering was extracted by cold dilute $(0.1 \mathrm{~N}) \mathrm{H}_{2} \mathrm{SO}_{4}$ and diluted tolliter by dilute $\mathrm{H}_{2} \mathrm{SO}_{4}$. (Vogel, 1974)

\section{Titanium Working Solution (10)ppm}

This solution is prepared by diluting $10 \mathrm{ml}$ of stock solution to $100 \mathrm{ml}$ with dilute $\mathrm{H}_{2} \mathrm{SO}_{4}$ in a volumetric flask.

\section{HHSNNA Reagent Solution}

This solution is prepared by dissolving $0.035 \mathrm{gm}$ of the compound in $25 \mathrm{ml}$ ethanol and complete to $100 \mathrm{ml}$ with distilled water in a volumetricflask.

\section{Acetate Buffer Solution (pH 4.5)}

This solution is prepared by dissolving $6.3 \mathrm{~g}$ of anhydroussodium acetate in a suitable amount of water; add $9.0 \mathrm{ml}$ of acetic acid (100) and water to make $100 \mathrm{ml}$. (Japanese Pharmacopoeia, 2016) Fluoride Stock Solution (100ppm)

This solution is prepared by dissolving $0.221 \mathrm{~g}$ of sodium fluoride (previously ignited at $400 \mathrm{C}^{0}$ ) inlliter distilled water. All fluoride solutionswere stored in polyethylene containers (Marczenko, 2000; Suresha et al., 2006).

\section{Fluoride Standard Solution (10ppm)}

This solution is prepared by diluting $10 \mathrm{ml}$ of stock solution to $100 \mathrm{ml}$ with distilled water in a volumetric flask.

\section{Recommended Procedure}

A $7 \mathrm{ml}$ of $10 \mu \mathrm{g} / \mathrm{mltitanium}$ solution is transferred into a $25 \mathrm{ml}$ calibrated flasks followed by addition of $3 \mathrm{ml}$ of $\mathrm{pH} 4.5$ buffer solution and aaliquots of sample solution containing 5-100 $\mu \mathrm{g}$ of fluoride, then followed by $5 \mathrm{ml}$ of HHSNNA solution.Dilute to volume with distilled water, mixed welland allow to standfor 5 minutesat room temperature. Measure the absorbance at $685 \mathrm{~nm}$ against a reagent blank containing no titanium and fluoride.

\section{Sampling}

Drinking water samples are taken from different provinces inMosul -Iraqand Zim-Zim (abundant, copious) water samples from Saudi Arabia. After the water samples weretransported to the laboratory, fluoride analyses were performed immediately.

\section{Determination of Fluoride in Water Samples}

$10.0 \mathrm{ml}$ sample was taken and, fluoride concentrations of all samples were determined in duplicate usingrecommended procedure and Eriochrome cyanine R - Zirconium (Marczenko, 2000). 


\section{Determination of Fluoride Tablets (Sinaflor and Zymafluor)}

Two different types of sodium fluoride tablets, provided from local markets were selected for analysis, to minimize a possible variation in the composition of the tablet, the mixed content of 10 tablets were weighed and grounded, then the powder equivalent to $1 \mathrm{mg}$ of fluoride is weighed into $100 \mathrm{ml}$ volumetric flask containing about $75 \mathrm{ml}$ of distilled water. It was shaken thoroughly for about 20-25 minutes, filtered through a whatman filter paper No. 40 to remove the insoluble matter and diluted to the mark with distilled water. Treat $10 \mathrm{ml}$ of this solution as mentioned under recommended procedure and Eriochrome cyanine R - Zirconium (Marczenko, 2000).

\section{RESULTS AND DISCUSSIONS}

Fluoride ion forms stable complexes with titanium (IV). Therefore, it is required to develop sensitive determination methods of fluoride ion. The reaction of titanium with HHSNNA has been investigated and the results indicated that the mole ratioof titanium to HHSNNAis 1:2 complex. This reaction has been used for the determination of titanium spectrophotometrically in aqueous solution of $\mathrm{pH} 4.5$ at $685 \mathrm{~nm}$ (Ahmad, 2002). This method was adopted for determination of fluoride through measurement of the quantitative decrease in the absorbance of the Ti-HHSNNA complex (bleaching the color of the complex), at $685 \mathrm{~nm}$ Fig. (1).

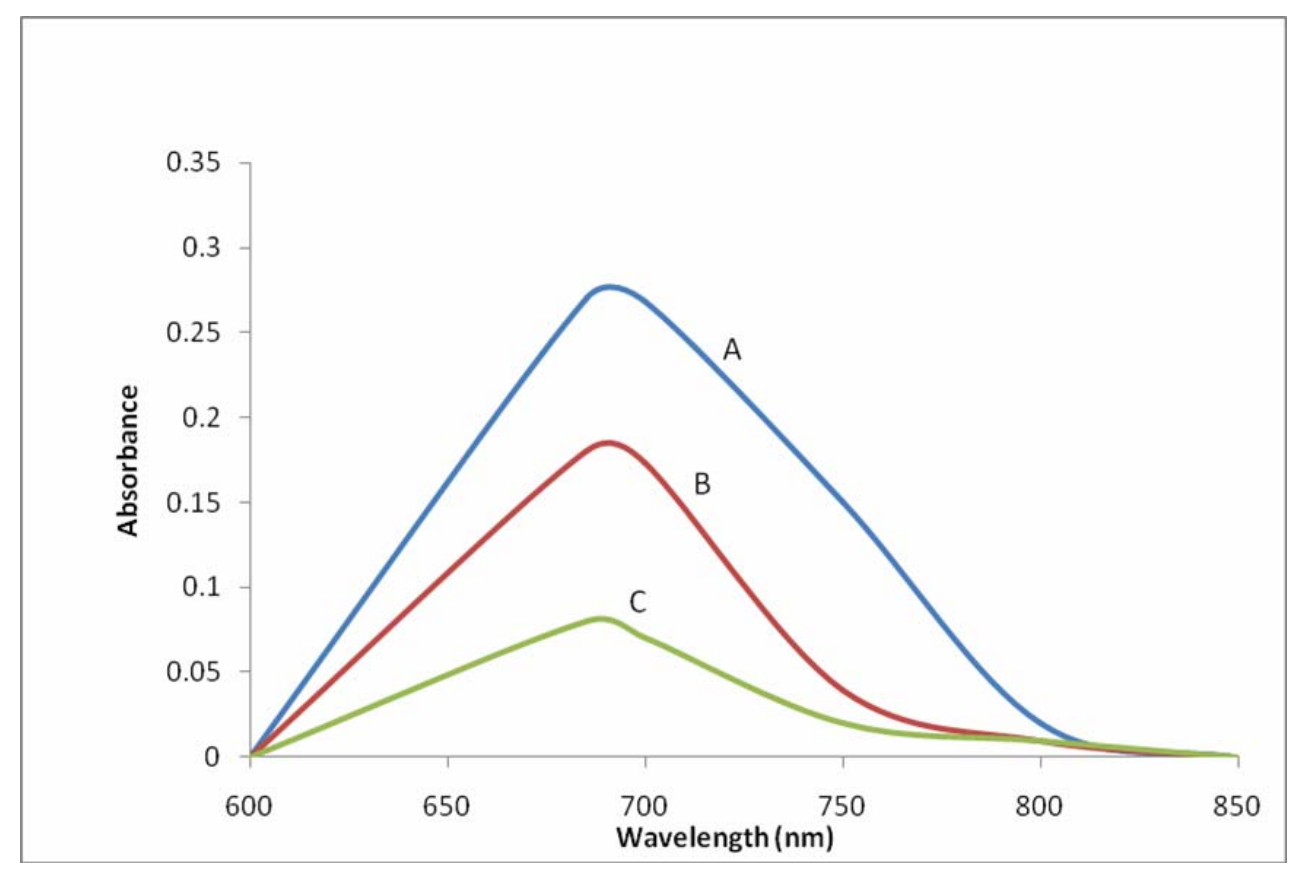

Fig. 1: Absorption spectra ofA: Ti-HHSNNA complex (70 $\mu$ gi) against blank.B: TiHHSNNA complex (70 $\mathrm{gg} \mathrm{Ti}+25 \mu \mathrm{g}$ fluoride)againstblank.C: Ti-HHSNNA complex

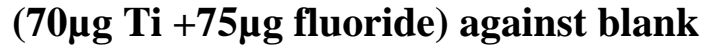

Employing the conditions described in therecommended procedure, a linear calibration graph of fluoride was obtained Fig. (2), which shows that Beer's law is obeyed over the concentration range $0.2-4 \mu \mathrm{g} / \mathrm{ml}$ with $\mathrm{R}^{2}$ of 0.9987 , intercept of 0.0001 and slope of 0.0614 . The conditional molar absorptivity of the product formed and sandell 's sensitivity was found to be $0.1166 \times 10^{4}$ $1 . \mathrm{mol}^{-1} \cdot \mathrm{cm}^{-1}$ and $0.016 \mu \mathrm{g} / \mathrm{cm}^{2}$ respectively. 


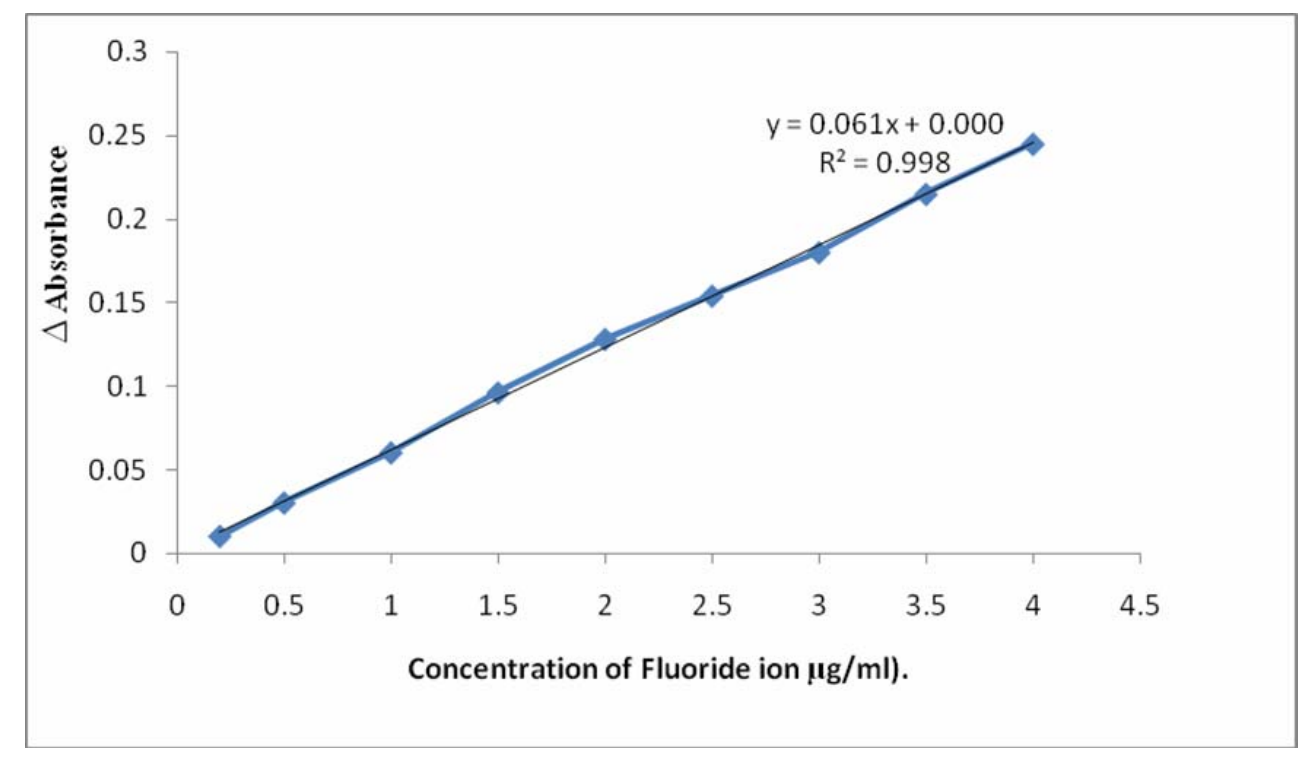

Fig. 2: Calibration graph of fluoride ion determination.

The accuracy and precision of the method are established by analyzing the pure fluoride solution at three different levels. The average recovery which is a measure of accuracy is $100 \pm 0.95$ revealing high accuracyof themethod. The relative standard deviation (RSD), which is an indicator of precision is better than $\pm 2 \%$. The results are complied in (Table 1).

Table 1: Optical characteristics and statistical data for regression equation of the proposed method

\begin{tabular}{|c|c|}
\hline Parameters & Value \\
\hline$\lambda$ max $(\mathrm{nm})$ & 685 \\
Beer's law limit $\left(\mu \mathrm{g} \cdot \mathrm{ml}^{-1}\right)$ & $0.2-4$ \\
Molar absorpitivity $\left(1 . \mathrm{mol}^{-1} \cdot \mathrm{cm}^{-1}\right)$ & $0.1166 \times 10^{4}$ \\
Determination coefficient $\left(\mathrm{R}^{2}\right)$ & 0.9987 \\
Regression equation(Y=a $\times \mathrm{Y}+\mathrm{b})$ & 0.0614 \\
Slope $(\mathrm{a})$ & 0.0001 \\
Intercept $(\mathrm{b})$ & $100 \pm 0.95$ \\
Recovery \% & $< \pm 2$ \\
\hline
\end{tabular}

\section{Application of real samples}

To evaluate the efficiency of the proposed method, it was used in determining of fluoride content of three water samples and their fluoride content were analyzed by the proposed method. The results were also compared statistically by student t-test with those obtained by Eriochrome cyanine $\mathrm{R}-$ Zirconiummethod, at 95\% confidence level. The calculated t- values did not exceed the theoretical values indicating that there was no significant differences between the precision of the proposed and literature method as cited in (Table 2). 
Table 2 : Determination of fluoride ion in water samples

\begin{tabular}{|c|cc|}
\hline Sample & \multicolumn{2}{c|}{ Amount of fluoride $\mathbf{~}$ g/ml *t-value } \\
& Proposed method Eriochrome cyanine R-Zirconium \\
\hline Tap water & 0.66 & 0.671 .18 \\
Zim-Zim(abundant, copious) water & 0.99 & 0.981 .2 \\
Bottled water (Life) & & 1.421 .441 .56 \\
\hline
\end{tabular}

*Average of ten determinations.

T values ( $\mathrm{n}=10$, at $95 \%$ confidence level tabulated value 2.262$)$.

For the determination of fluoride in pharmaceutical preparation (tablets) the results of the assay of the pharmaceutical preparations revealed that there is a close agreement between the results obtained by the proposed method, Eriochrome cyanine R-Zirconium method and the label claim (Table 3).

Table 3: Determination of fluoride ion in pharmaceutical preparation (tablets)

\begin{tabular}{|c|cc|}
\hline Pharmaceutical formulations (Tablets) & $\begin{array}{c}\text { Amount of fluoride } \mathbf{\mu g} / \mathbf{m l} * \\
\text { Proposed-Eriochrome cyanine R-Zirconium- } \\
\text { Method }\end{array}$ & $0.449 \mathrm{mg} / \mathrm{tab}$ \\
\hline $\begin{array}{c}\text { 1-Sinaflor tablets [Avicenna. Prod. Damascus-Syria] } \\
\text { 0.45mg/tab }\end{array}$ & $0.448 \mathrm{mg} / \mathrm{tab}$ & $0.497 \mathrm{mg} / \mathrm{tab}$ \\
$0.5 \mathrm{mg} / \mathrm{tab}$ & $0.504 \mathrm{mg} / \mathrm{tab}$ & \\
\hline
\end{tabular}

*Average of tendeterminations.

\section{Application of the Proposed Method to Content Uniformity}

Content uniformity or the uniformity of dosage unit was defined as the degree of uniformity in the amount of active substance among dosageunits (Ahmad, 2017). The proposed method proved to be suitable for the content uniformity test, where a great number of assays on individual tablets are required. Data presented in (Table 4) indicate that the proposed method can determine accurately and precisely quantities Fluoride $(0.45 \mathrm{mg})$ in its commercially available tablets. The mean percentage (with RSD\%) of the labeled claim found in ten tablets was (1.8\%) which falls within the content uniformity limits specified by the USP 33 (United State Pharmacopeia, 2010).

Table 4: Content uniformity testing of fluoride tablets bythe proposedmethod

\begin{tabular}{|r|c|}
\hline \multicolumn{1}{|c|}{ Parameter } & \% of the label claim \\
\hline Mean(X)of ten individual tablets & 99.55 \\
\% RSD & $1.8 \%$ \\
Max. allowed unit (USP.2010) & $\pm 15 \%$ \\
\hline
\end{tabular}

\section{CONCLUSION}

In this work, simple and preciseindirect colorimetric method is developed and validated for the determination of fluoride ion in pharmaceutical preparations (tablet) and different water samples. The method does not need heating or solvent extraction step. The method relies on the use of simple and cheap chemicals and techniques and can be used for routine determination and quality control of fluoride ion. 


\section{REFERENCES}

Ahmad, N.R. (2017). High performance liquid chromatographic method for the determination of chlordiazepoxide in pharmaceutical preparations: Application to content uniformity testing, AJPS. 17(2), 45-51.

Ahmad, N.R. (2002). Spectrophotometric determination of Titanium in some pharmaceutical formulations. J. Edu. Sci., 14(3), 15-20.

Barghouthi, Z.; Amereih, S. (2012). Spectrophotometric determination of fluoride in groundwater using resorcin blue complexes. American J. Analytical Chem., 3, 651-655.

British National Formulary (BNF), (2016). Royal Pharmaceutical Society. 70, 991.

Dutta, J.; Nath, M.; Chetia, M.; Misra, A. (2010). Monitoring of fluoride concentration in ground water of small tea gardens in sonitpur district, Assam, India; Correlation with physicchemical parameters. International J. Chem. Tech. Research, 2(2), 1199-1208.

Farajzadeh, M. (2004). An extractive-spectrophotometric method for determination of fluoride ions in natural waters based on its bleaching effect on the iron (III)-thiocyanate complex. $J$. Chinese Chem. Soc., 51, 303-308.

Javad, Z.; Akram, S.; Azimi, G.; Ghasemi, J. (2009). Spectrophotometric determination of trace amount of fluoride using Al-Xylenol orange complex as a colored reagent. Analytical Sci., 26,1249-1253.

Lida, R.; Mehdi, M.; Fatemeh, F.; Seyed, M.; Amir, H. (2013). Evaluation of ground water fluoride concentration in Hamada province West of Iran (2012). Iranian J. Health Sci., 1(3), 71-76.

Marczenko, Z. (2000). "Spectrophotometric Determination of Elements". Ellis Harwood Limited Chichester, pp. 191-193.

Okibe, F.; Ekanem, E.; Shallangwa, G.; Ekwumemgbo, P.; Sallaw, M.; Abanka, O. (2010). Fluoride content of soil and vegetables from Irrigation River. Galma, Zaria, Nigeria. Australian $J$. Basic and Applied Sci., 4(4), 779-784.

Suresha, M.; Abdul Galil, M.; Gowtham, M.; Nageudrappa, G. (2006). Spectrophotometric determination of fluoride in drinking and wastewater. J. Saudi Chem. Soc, 10(2),219-224.

Sweetman, S.C. (2009). "The Complete Drug Reference". Editors, Martindale. $36^{\text {th }}$ ed. London: Pharmaceutical Press, 1962 p.

The Japanese Pharmacopoeia, (2016). "The Ministry of Health, Labor and Welfare". $17^{\text {th }}$ ed., English Version, 193 p.

The United State Pharmacopeia (2010). 33-NF 28, 418 p.

Tokalioglu, S.; Kartal, S.; Sahin, U. (2004). Determination of fluoride in various samples and some infusions using a fluoride selective electrode. Turk. J. Chem., 28, 203-211.

United States Pharmacopeia and National Formulary. (2018). USP 41, NF 36. 3790 p.

Vogel, A.I. (1974). "Macro and Semi Micro Qualitative Inorganic Analysis". $4^{\text {th }}$ ed. Longman, London, $598 \mathrm{p}$.

WHO, (2004). "Guidelines for Drinking-Water Quality Recommendation". $2^{\text {nd }}$ ed., Vol. 1, World Health Organization, Geneva, pp. 375-377. 